RESEARCH ARTICLE

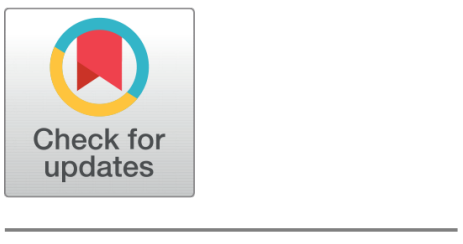

open ACCESS

Received: 20.07.2021

Accepted: 27.10 .2021

Published: 29.11.2021

Citation: Wisnubroto DS, Ruslan R, Irawan D, Wijayanti TE (2021) Is West Kalimantan More Suitable for Constructing the First Nuclear Power Plant in Indonesia Compared with Bangka Belitung? Analysis of Public Surveys in those Two Provinces. Indian Journal of Science and Technology 14(40): 3014-3025. https://doi.org/

10.17485/IJST/v14i40.1111

* Corresponding author.

djarot@batan.go.id

Funding: None

Competing Interests: None

Copyright: (c) 2021 Wisnubroto et al. This is an open access article distributed under the terms of the Creative Commons Attribution License, which permits unrestricted use, distribution, and reproduction in any medium, provided the original author and source are credited.

Published By Indian Society for Education and Environment (iSee)

ISSN

Print: 0974-6846

Electronic: 0974-5645

\section{Is West Kalimantan More Suitable for Constructing the First Nuclear Power Plant in Indonesia Compared with Bangka Belitung? Analysis of Public Surveys in those Two Provinces}

\author{
Djarot Sulistio Wisnubroto $^{1 *}$, Ruslan Ruslan ${ }^{1}$, Dimas Irawan ${ }^{1}$, \\ Theresia Erni Wijayanti ${ }^{1}$ \\ 1 National Nuclear Energy of Indonesia, BATAN
}

\section{Abstract}

Objectives: This study aims to analyze the public perceptions of Bangka Belitung and West Kalimantan towards developing nuclear power plants (NPP) in Indonesia so that the Government gets input in choosing a suitable location to construct the first NPP in the future. Methods: The survey in Bangka Belitung was held in 2017, while in West Kalimantan in 2019. Quantitative research methods were carried out through face-to-face interviews. Using a total sample of 800 respondents for Bangka Belitung and 600 respondents for West Kalimantan gave a margin of error of $\pm 1.8 \%$ at a confidence level of 95.0\%. Findings: The Bangka Belitung residents, whose electricity has been met with relatively more minor disruption and blackouts, tended to reject nuclear power plants (51.75\% support and $48.25 \%$ reject). On the other hand, due to constraints in fulfilling electricity needs and the sentiment factor of electricity imports from Malaysia, the West Kalimantan public supports the Indonesian nuclear power program ( $87.17 \%$ support and $12.83 \%$ reject). Furthermore, West Kalimantan is more likely to be the first location for NPPs. Novelty: For the first time, a study to compare people's perceptions of the two provinces was conducted. Interestingly, there are similarities in those two provinces, which tend to choose renewable energy if available over nuclear energy. As the support from the West Kalimantan public for the nuclear power plant is probably for pragmatic reasons, it is to be questioned if this support will remain sustainable if coal-fired power plants can soon solve the electricity problem in the area.

Keywords: Nuclear Energy; Indonesia; Bangka Belitung; West Kalimantan; public survey

\section{Introduction}

The Government of Indonesia has for more than 40 years had a nuclear power plant (NPP) preparation program, but the NPP has not been realized until now. Indonesia's 
main reason to consider nuclear energy is that its current dependency on fossil energy sources is around $85 \%$. The coal and gas reserves will be exhausted in the coming decades. Meanwhile, Indonesia's current population is more than 270 million people and increasing by $1.3 \%$ per year, and the average annual economic growth is above $5 \%{ }^{(1)}$. Solutions must be sought to meet energy needs according to these developments. Another consideration is that Indonesia has committed to reducing greenhouse gas emissions by $29-41 \%$ by 2030 . Consequently, there is no other way but to utilize low-carbon energy sources, including nuclear.

Nevertheless, on the contrary, in the national energy policy, the Government of Indonesia still considers nuclear energy as a last resort ${ }^{(2)}$. The word "last resort" has become a heated debate among energy observers in Indonesia. For the anti-nuclear group, it means that Indonesia will not use nuclear energy if other options, including fossil energy, exist. Also, their perception that Indonesia has relatively abundant potential for renewable energy sources has led to a firm rejection of nuclear energy use $^{(3)}$. On the other hand, the pro-nuclear group states that economic growth and reduction of carbon emissions in the next few decades cannot be achieved without nuclear energy ${ }^{(4)}$. Meanwhile, the rhetoric from Indonesian officials regarding nuclear energy has been quite confusing ${ }^{(5)}$. This situation may cause the State Electricity Company (PT PLN) to not include nuclear energy options in the Electricity Supply Business Plan (RUPTL) for the period of 2019-2028 ${ }^{(6)}$.

Even so, the Government of Indonesia continues to carry out preparatory activities to construct nuclear power plants. These programs are carried out by the National Nuclear Energy Agency of Indonesia (BATAN) in a research and development framework. Interestingly, those programs are not part of the Ministry of Energy's program. This situation may signify that the Government of Indonesia is still considering various socio-political factors before building a nuclear power plant. In 1991-1996, multiple activities were carried out within the program, searching for prospective nuclear power plant locations in Java, which finally resulted in the choice of a site in the Muria Peninsula in Jepara, Central Java ${ }^{(7,8)}$. Java is the most industrialized part of Indonesia and has the highest energy needs. Its population of 150.4 million comprises $56.3 \%$ of Indonesia's total population, making Java the most populous island in the world. With an area of $127,569 \mathrm{~km}^{2}$, it is also densely populated with a population density of 1,179 people $/ \mathrm{km}^{2(9)}$. However, due to a massive anti-nuclear demonstration in 2006, the nuclear power plants program on that location was halted.

In the last ten years, the Government of Indonesia has focused on developing energy infrastructure outside Java, including the possible use of nuclear energy. Two regions are considered to be candidates for the location of NPPs, namely Bangka Belitung and West Kalimantan. The location of those two provinces can be seen in Figure 1.

In 2011-2013, the Government of Indonesia conducted a feasibility study (FS) on the Bangka Belitung islands, which resulted in the choice of two locations, namely West Bangka and South Bangka ${ }^{(10)}$. This activity in Bangka Belitung was at the provincial governor's request ${ }^{(10)}$. The FS's purpose was to meet electricity needs in Bangka Belitung and Sumatra Island and then be connected to Java's electricity system. Meanwhile, to support the acceleration of the "go nuclear" decision process by the Government, Indonesia had also conducted the promotion and dissemination of nuclear technology to many regions in Indonesia. It continued with a survey of public opinion on the possible use of nuclear energy. The National Nuclear Energy Agency (BATAN) conducted a public opinion survey related to the nuclear power plant program on a national scale in 20102016, and more specifically for Bangka Belitung in 2010-2014. The activities carried out by Indonesia in this continuous public survey are far more advanced and transparent compared to similar activities carried out in several Southeast Asian countries ${ }^{(11-14)}$. However, it is not easy to compare public surveys in Indonesia with surveys conducted in countries with nuclear power plants because their public has already benefited from nuclear energy ${ }^{(15)}$. Overall, the national survey results, except for 2011 during the Fukushima Daiichi accident, indicated the public's tendency to support nuclear power plant construction. Even in the 2014-2016 period, the level of support was above 70\%. However, the opposite results occurred for a local survey for the Bangka Belitung community in the 2010-2014 period. During that period, the nuclear energy program's support was always lower than national survey results. Most people on the islands opposed the construction of nuclear power plants on Bangka Island. The opposition even reached a peak in 2012 when only $28 \%$ of respondents supported the NPP program ${ }^{(16)}$.

There are several possible causes of differences in national surveys and local Bangka Belitung surveys:

1. There was a not in my backyard (NIMBY) phenomenon, where Bangka Belitung people might agree to build nuclear power plants in Indonesia if they were not in their neighborhood.

2. The 2011 Fukushima Daichi accident's impact caused trauma to some people in Bangka Belitung because they perceived the Government was building a nuclear power plant near them.

3. The local political situation, such as the gubernatorial election process, amplified anti-nuclear issues. The nuclear power plant program became unpopular with most of the Bangka Belitung populace in that period.

Three years later, in 2017, a survey was conducted again in the islands to determine whether there was a change in people's perception of Indonesia's nuclear energy. This activity was one of the Government of Indonesia's assets to find out whether 
Bangka Island will continue to be used as a prospective nuclear power plant location or not in the future.

On the other hand, in the last three years, there has been a strong desire from the West Kalimantan provincial government to consider using nuclear energy to supply the electricity in the province on the following grounds:

1. To fulfill current needs, some electricity is still imported from Malaysia ${ }^{(17)}$

2. Future industrialization will necessitate a greater electricity supply ${ }^{(18)}$

3. West Kalimantan has a relatively minimum earthquake potential ${ }^{(19)}$; therefore, the local public might perceive their province as suitable for constructing a nuclear power plant.

For the aforementioned reasons, the Government has arranged a medium-term program, including NPP development in West Kalimantan. BATAN plans to conduct a feasibility study of a nuclear power plant in West Kalimantan in the 2021-2024 period ${ }^{(20)}$. However, before the feasibility study is carried out, in 2019, BATAN had conducted a public opinion survey in West Kalimantan regarding their perceptions of the Indonesian NPP program. Even in 2021, there is already a site study with multicriteria analysis using geographic information system (GIS) techniques that lead to locations in the Bengkayang district ${ }^{(21)}$.

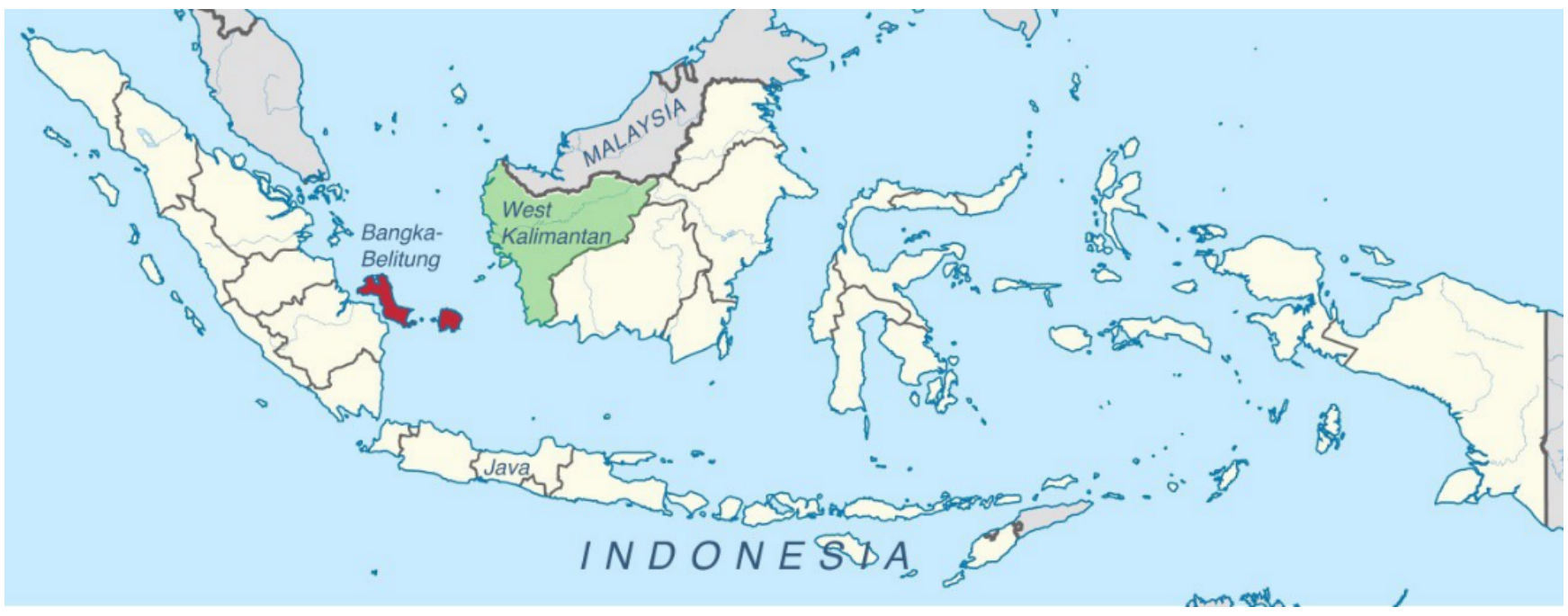

Fig 1. Map of Indonesia showing the location of Bangka Belitung and West Kalimantan

This is the first paper comparing and discussing the Bangka Belitung and West Kalimantan public opinion surveys conducted in 2017 and 2019. The aim is to analyze the public perceptions of the two provinces on the national NPP program. It is expected that the result will aid policymakers in choosing a suitable location to build the first Indonesian nuclear power plants in the future. Differences in public survey results from the two regions were analyzed using each province's socio-political, economic, and cultural characteristics.

\section{Methodology}

The survey in the two provinces was carried out following precisely the same method as the previous national surveys (in 2010-2016) and local Bangka Belitung surveys (in 2010-2014) ${ }^{(3)}$, to find out changes in public opinion in Bangka Belitung and compare it with the opinion of the people of West Kalimantan.

Quantitative research methods were carried out through face-to-face interviews with respondents using a questionnaire. By using a total sample of 800 respondents for Bangka Belitung, and 600 respondents for West Kalimantan, a margin of error of $\pm 1.8 \%$ at a confidence level of $95.0 \%$ was attained. The sampling technique used was multistage random sampling and simple random sampling so that variability and probability were represented equally in the sampling point and respondent. The smallest sampling unit in this survey was the village. The villages were divided into the urban and rural village categories. The respondents' selection was prepared so that each resident of these two provinces has an equal chance of being questioned.

The implementation of the public poll was carried out by survey institutions from local universities (Bangka Belitung University for Bangka Belitung, and Tanjungpura University for West Kalimantan) and assisted by the local offices of the Central Bureau of Statistics (BPS). 
The premade questionnaire used the Indonesian language or was translated into local languages if needed. For face-to-face interviews, BATAN provided the interviewers with general knowledge of nuclear science and technology. The results reflect the opinion of the entire population of Bangka Belitung and West Kalimantan and are segmented by age, sex, residence, education, and purchasing power.

The analysis of survey results focused on answering the following three questions:

1. What were the differing perceptions of West Kalimantan and Bangka Belitung's people on the Indonesian Nuclear Energy program?

2. Was there a difference in the NPP program's support directly proportional to each province's energy needs?

3. How did the community's social and economic condition affect the results of the survey?

\section{Results and Discussion}

Bangka Belitung and West Kalimantan are similar in that both are among the regions in the Indonesian archipelago relatively free of earthquakes and tsunami. As a result, the two locations become the leading choice to avoid these natural disasters.

The Bangka Belitung Province consists of two main islands, Bangka and Belitung, with a total area of $16,424.14 \mathrm{~km}^{2}$ with a population density of 92.4 people $/ \mathrm{km}^{2}$. The West Kalimantan province's area is $146,807 \mathrm{~km}^{2}$, with a density of 34.25 people $/ \mathrm{km}^{2}{ }^{(9)}$. The survey in West Kalimantan was challenging due to its natural conditions since its population was relatively sparse. At the same time, Bangka Belitung was more accessible because of its smaller area and higher population density.

More than 70\% of the Bangka Belitung population are of the Malay ethnic group, not unlike Sumatera and the Malaysian Peninsula. On the other hand, West Kalimantan has a multiethnic population; it consists of various ethnic groups from all over Indonesia, and only 30\% are local natives (Dayak ethnic). From the political side, the two provinces are similar; most of the regional parliament's political parties support the central Government. Nevertheless, there are significant differences in the economic parameter. In 2017, the annual expenditure per capita of Bangka Belitung was Indonesian Rupiahs (Rp.) 12.66 million, while West Kalimantan was Rp. 8.86 million ${ }^{(22)}$. Although the two provinces' welfare level was lower than the national average, the Bangka Belitung people were more prosperous than the West Kalimantan people. This indication was also evident in the annual export value of each province. Although the area and population are smaller, in 2018, the export value of Bangka Belitung was US $\$ 1.39$ billion, slightly exceeding West Kalimantan with an export value of US\$ 1.37 billion ${ }^{(23)}$. Bangka Belitung's main product is tin, while West Kalimantan's main products are inorganic chemicals, minerals, and forest products.

With such geographic, demographic, political, and economic backgrounds, their characteristics in responding to the nuclear energy program in Indonesia can be analyzed by considering their source of information and their perception of nuclear technology and energy, as follows:

\section{Where did people get their information?}

The study of where the media people obtain information from is significant in this survey. It can provide an overview of public knowledge about national issues and energy issues, including information about nuclear. Furthermore, it is also essential to determine which media have a significant influence on society.

After the fall of the Suharto regime in 1998, Indonesia experienced democratization. The consequence is the growth of various mass media, including TV, newspapers, radio, and the internet, which are freer than in the previous era. The public can enjoy various alternative sources of news from both national and local mass media. However, depending on the local community's welfare and local infrastructure, the information media users are not evenly distributed in Indonesia.

The geographical and demographic differences between these two provinces may affect the way local people obtain information. As shown in Figure 2, interestingly, among the residents of Bangka Belitung, the four most effective media outreach was through direct chat, TV, radio, and local newspapers. The internet was only ranked fifth. It was different from the national survey results showing that Indonesians always place TV as the primary medium for information ${ }^{(16)}$. Moreover, even though the Bangka Belitung residents' welfare level was relatively good, it turns out that the internet was less popular than radio and local newspapers. However, this internet problem could be because the islands' network infrastructure had not reached the villages.

Nevertheless, what is clear is that the people of Bangka Belitung have a unique characteristic that emphasizes direct conversation as the leading media in obtaining information. Also, besides TV, they still considered radio and local newspapers as adequate media. This possibility was due to the geographical influence of living on small islands, resulting in emotional closeness between residents. The Bangka Belitung community's unique nature in using chat as the primary tool for exchanging information is supported by several previous studies. The culture of the people there trusts face-to-face communication more 
than other media ${ }^{(24,25)}$. Of course, this situation needs to be further explored and compared with the characteristics of other small island populations with similar levels of welfare.

Meanwhile, among the people of West Kalimantan, the TV was a very dominant media, followed by the internet, while chatting occupied a smaller portion. At the same time, newspapers and radio contributed a tiny percentage. It is possible that the low population density and spread-out residences cause the TV to be an efficient medium to get information and socialize. A far lower percentage was exhibited by the internet. Compared to the Bangka Belitung public's perception, the use of chatting to obtain information in West Kalimantan was less prominent.

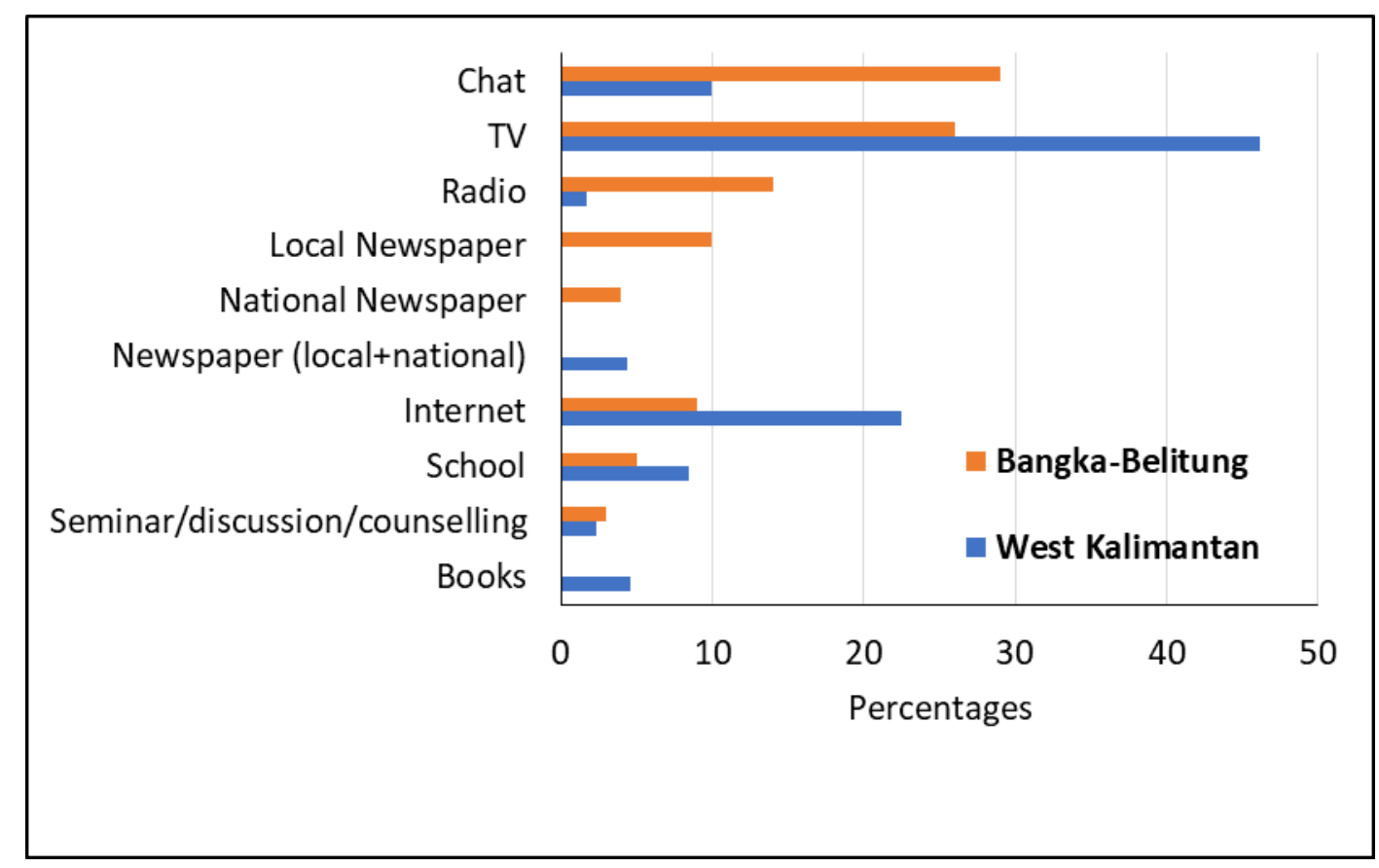

Fig 2. Media sources to get the information

It is also interesting to notice that although Bangka Belitung was more prosperous than West Kalimantan, internet usage in the community was lower than in West Kalimantan. It was consistent with a poll conducted by the Indonesian Internet Service Providers Association in 2017; internet users in Bangka Belitung comprised only $70 \%$ of the total population. In West Kalimantan, they exceeded $80 \%{ }^{(26)}$.

The people of Bangka Belitung might be more inclined to focus on local issues that occur around them. In contrast, West Kalimantan people depended very much on TV because of the low population density. Because the Indonesian television networks mainly broadcast national events rather than the local, their audience would probably be relatively more affected by broader issues. West Kalimantan people probably saw these issues regarding individual or group or their province needs and linked them to problems at the national level. Those conditions probably also influence the differing public perceptions in the two provinces regarding nuclear energy use. Also, the composition of West Kalimantan's people was more heterogeneous. Thus, a positive impact was that they were more open than the Bangka Belitung people. The adverse effect, namely inter-ethnic conflicts that have occurred several times in the West Kalimantan, will be explained in several later pages.

\section{Perception of nuclear technology}

As shown in Figure 3, the two provinces' public perceptions regarding nuclear technology use were mainly related to energy. For Bangka Belitung, the percentage even reached 76\%. Perhaps nuclear power had become a controversial topic in the province a few years earlier when BATAN carried out the feasibility study in 2011-2014. However, the Bangka Belitung case's uniqueness was that the proportion of the respondents who answered they did not know about nuclear technology was quite significant (11\%) and exceeded the public perception of nuclear technology for weapons, health, and industry.

On the other hand, West Kalimantan people also considered that nuclear technology's most prominent use was for electrical energy (59.67\%). However, different from Bangka Belitung results, there was a significant percentage of their perception of the 
application for weapons (18.17\%) and health (13\%), while only $2 \%$ of people perceived themselves as not knowing about nuclear use.

The results related to the utilization of nuclear technology might confirm that West Kalimantan people tended to have a broader perception of nuclear technology. In contrast, the Bangka Belitung people might be more likely to have a strong memory of the feasibility study of nuclear power plants carried out on Bangka Island in the past. These results supported the previous explanation related to the use of media to obtain information. Bangka Belitung islands community was more focused on local issues, while West Kalimantan tended to have a more extensive understanding.

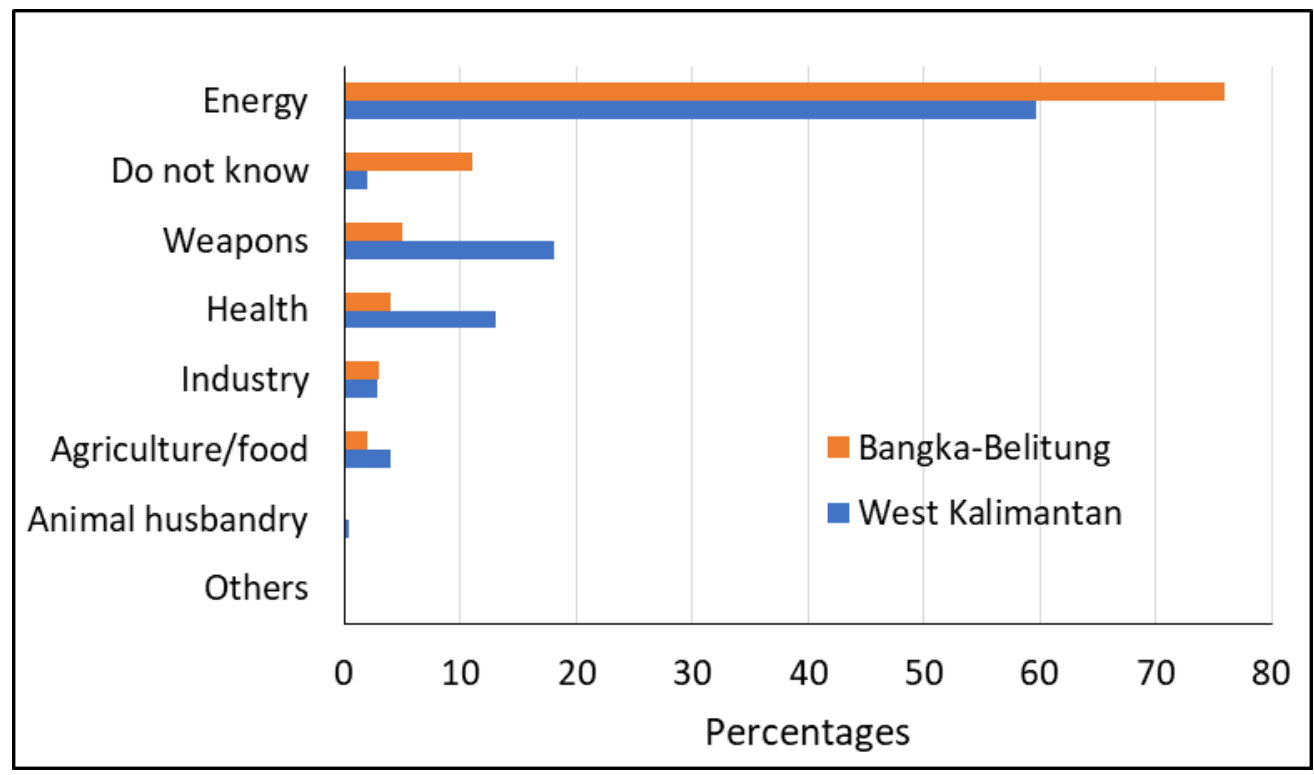

Fig 3. Public perception of the utilization of nuclear technology

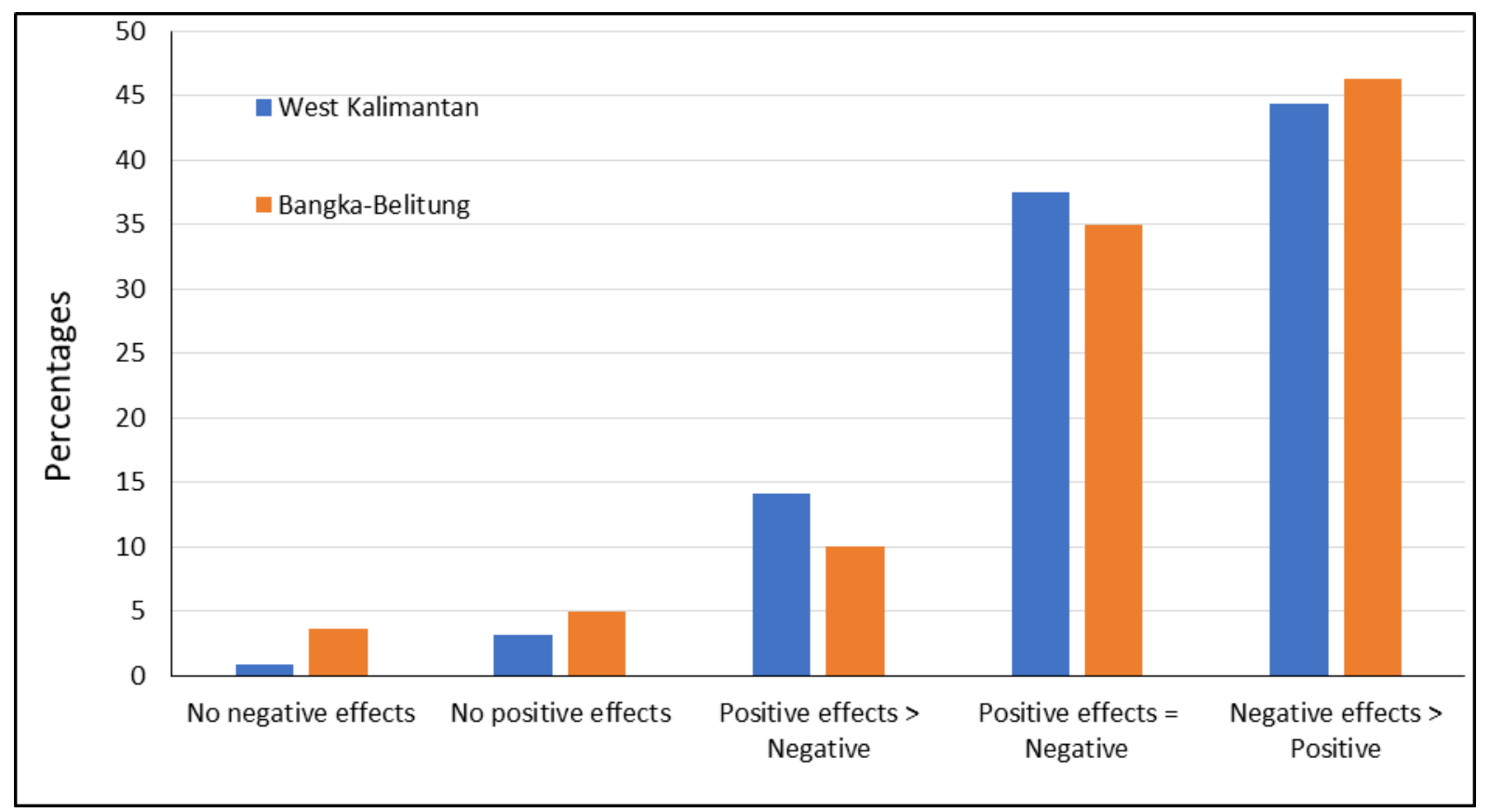

Fig 4. Perceptions of the effect of nuclear technology 
Figure 4 shows that the two provinces' people had almost the same perception related to the impact of nuclear technology. The most common public perception was that nuclear technology's harmful effects outweigh the positives (Bangka Belitung: 46.3\%, West Kalimantan: $44.33 \%$ ). Then, at a somewhat lower percentage, followed the perception that the positive and negative impacts were equal. Much less common was the perception that the positive effect was greater than the negative. This perception probably indicates that news about nuclear in the media, regardless of media sources, was more on negative topics such as nuclear accidents, radiation contamination, or weapons conflicts between countries that affect people's perceptions in both provinces. A qualitative study reinforces this result in a West Kalimantan district that nuclear power plants' image was associated with atomic bombs and nuclear accidents ${ }^{(27)}$. It could also mean that the Government of Indonesia, through BATAN as a nuclear technology promoter organization, had not successfully promoted the utilization of nuclear technology. The ineffective promotion might be due to a limited budget for socialization and dissemination to reach large areas in Indonesia.

\section{Perception of Nuclear Energy}

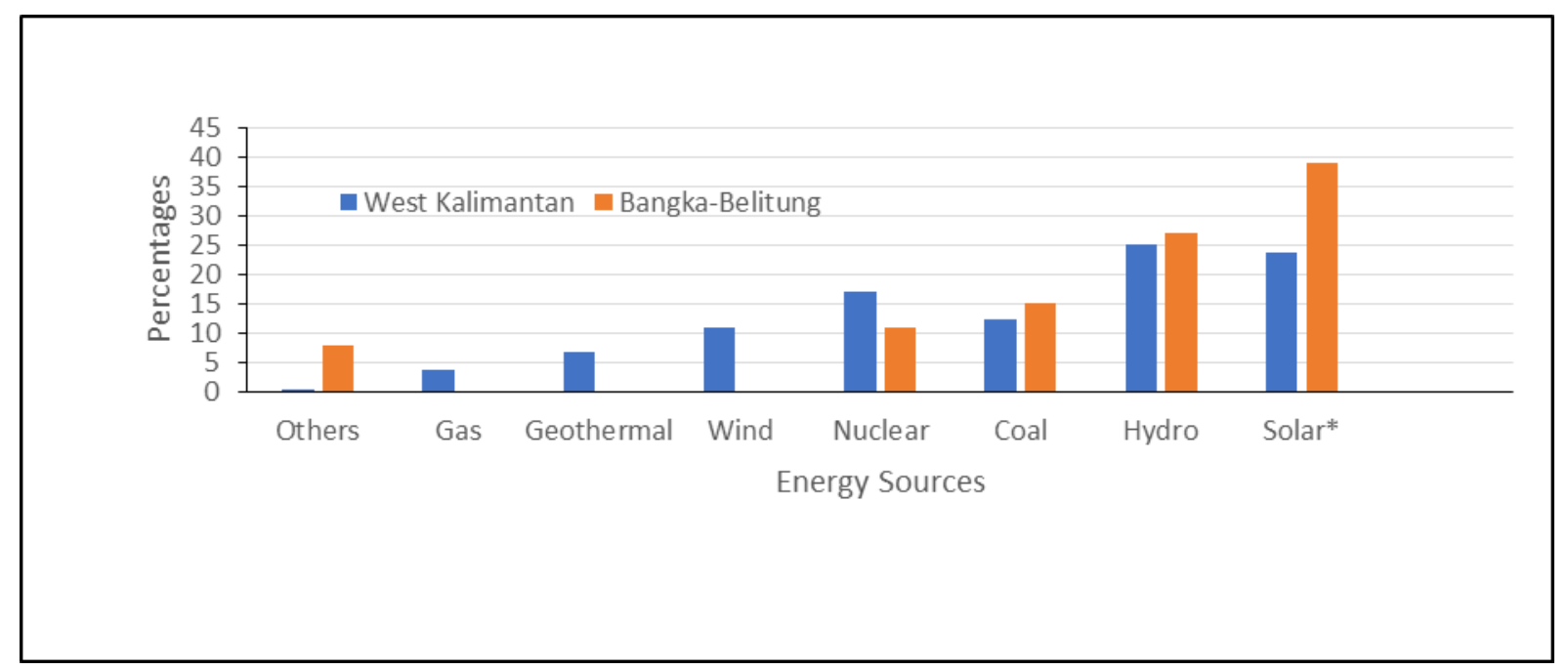

Fig 5. Public perception of the order of preference of energy sources.

Although this survey used a national nuclear power plant program theme, it was possible that the respondents interpret that the nuclear power plant was associated with where they live without explicitly mentioning the location. Figure 5 shows that the people of Bangka Belitung and West Kalimantan prioritized renewable energy, specifically solar and hydropower. It is possible that they perceive that in tropical countries such as Indonesia, the sunlight radiating throughout the year has great potential. Therefore, the Government should optimize the use of solar energy. The people of Bangka Belitung assumed that solar power was the first choice for fulfilling their province's energy needs.

On the other hand, West Kalimantan people prioritized hydropower, which is a logical reason because it has many rivers, including the Kapuas River, the longest river in Indonesia. Several researchers also stated that West Kalimantan is a province with the highest hydropower and mini/micro hydro potential in Indonesia ${ }^{(28,29)}$. The opinion of the West Kalimantan public placed NPP in the third position after hydropower and solar. In contrast, the Bangka Belitung public put nuclear energy in the fourth position after solar, hydropower, and coal. The fundamental difference between Bangka Belitung and West Kalimantan people was that the West Kalimantan people's perceptions of energy were quite extensive; they also considered wind, gas, and geothermal energy options. Although it does not face political challenges such as nuclear energy, people's high hopes for utilizing renewable energy, unfortunately, face challenges in regulations, finances, operations, and scattered locations ${ }^{(30)}$. The contribution of renewable energy in Indonesia is currently approximately only $13 \%$ of the total energy used.

When the question was more focused on using nuclear energy in Indonesia, there was a significant difference between those two provinces. As shown in Figure 6, the Bangka Belitung public tended to reject the use of nuclear power plants (48.25\% agree, and $51.75 \%$ disagree), while the public of West Kalimantan, on the contrary, strongly supported NPPs with a massive percentage (87.17\% agree, and $12.83 \%$ disagree). For the Bangka Belitung case, possible reasons are memories with the controversy of the feasibility study of NPPs on the Bangka Island at almost the same time as the Fukushima Daiichi accident in 2011. Moreover, at that time, in Bangka Island, there were demonstrations by anti-nuclear groups. 

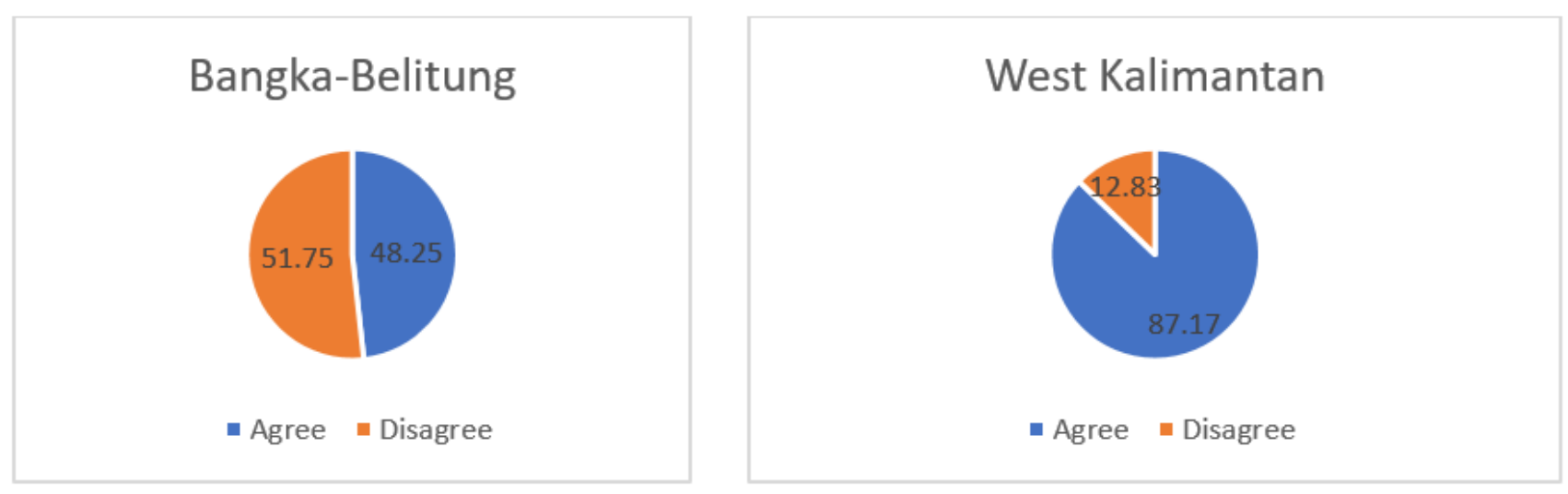

Fig 6. Opinions of Bangka Belitung and West Kalimantan public on nuclear energy in Indonesia

However, there are probably other reasons that distinguished public perception in the two provinces regarding the use of nuclear power, including electrification ratio and frequency of blackouts or other electrical disturbances. Five of those reasons are discussed as follows:

\section{a. Electrification ratio}

In the last four years, the electrification ratio of Bangka Belitung is the same as Jakarta's capital city, almost $100 \%$. It means that the entire community is satisfied with the electricity situation. On the other hand, the condition of the electrification ratio of West Kalimantan in 2018 was $88.09 \%{ }^{(31)}$. It means that there were still more than $10 \%$ of the households in the province that could still not enjoy electricity. Furthermore, the definition of the electrification ratio is simple, namely the percentages of Indonesian households that have been provided some form of electricity supply divided by the total number of households. The electrification ratio does not consider the supply quality; for example, it does not consider whether the electricity supply is genuinely 24 hours a day. In West Kalimantan, the state electricity company could only provide $82.9 \%$ of the power; the rest was through private sectors or individual efforts.

The Government of Indonesia plans to increase the electrification ratio in the future for each province. By 2024, for West Kalimantan, it is targeted at $95 \%$, to be attained by implementing a village electricity program using micro-hydropower and solar panels, among other means. In the future, it will be necessary to study whether increasing the electrification ratio will change local community support for the nuclear power plant program.

\section{b. Frequency of blackouts/electrical disturbances}

Almost all regions outside Java often face power outages, which is usually a local community complaint. The outages or disruptions are stated as the System Average Interruption Duration Index (SAIDI) and the System Average Interruption Frequency Index (SAIFI). SAIDI is the average outage duration (hours) for each customer served in one year, while SAIFI is the average number of interruptions that a customer would experience in one year. Table 1 below shows the differences between SAIDI and SAIFI in Bangka Belitung and West Kalimantan in 2017-2018.

\begin{tabular}{lll}
\multicolumn{3}{l}{ Table 1. SAIDI and SAIFI conditions in Bangka Belitung and West Kalimantan } \\
& SAIDI (hours/year) 2017 2018 & SAIFI (times/year) 20172018 \\
\hline Bangka Belitung & 7.074 .80 & 5.694 .54 \\
West Kalimantan & 20.1217 .83 & 24.3923 .82 \\
\hline
\end{tabular}

The difference in the electrical disturbance index was very significant. Bangka Belitung residents were enjoying electricity with relatively little disruption, while West Kalimantan residents often complained of power outages and disruptions throughout 2017 and 2018. 


\section{c. Electricity imports from Malaysia}

In recent years, the National Electric Power Company (PT. PLN) imports electricity from Sarawak, Malaysia, to fulfill the electricity demand in West Kalimantan. Sarawak is located north of West Kalimantan. The power imported from Malaysia has been around 170-230 MW until now ${ }^{(33,34)}$. It is logical since West Kalimantan has limited energy resources. The history of relations between Indonesia and Malaysia had included conflict in the 1960s and fluctuating ties between the two countries, causing this electricity import to be a controversial issue ${ }^{(35,36)}$. The relationship between Indonesia and Malaysia has always had its ups and downs. Its history began in 1963; there was a confrontation between Indonesia and Malaysia. This war originated from Malaysia's desire to merge Brunei, Sabah, and Sarawak into the Malay Land Alliance in 1961. Since then, several frictions have occurred between the two countries, such as territorial disputes, mutual claims for cultural products, and Indonesian workers' treatment in Malaysia. Also, there were frequent controversial statements from both sides. With that historical background, a number of people responded emotionally and demanded that the Government meet its own electricity needs without being dependent on Malaysia ${ }^{(37)}$.

On the other hand, such a situation did not occur in Bangka Belitung because the community was satisfied with the electricity supply, almost entirely supplied by PT. PLN.

Several new power plants are being built in West Kalimantan, particularly coal-fired power plants ${ }^{(38)}$. When these power plants, with a total capacity of around 1,000 MW, enter the West Kalimantan electricity system in 2022, electricity imports can be reduced. There is a possibility that the Indonesian utility company will turn into an exporter of electricity to Malaysia during peak loads. Whether the West Kalimantan people's support for the development of nuclear power plants will decrease under such a situation is a topic worthy of more in-depth study.

\section{d. Leaders' statements}

Several times, the governor and community leaders of West Kalimantan have called openly and formally to use nuclear power plants to meet today's society's needs, reduce electricity imports from Malaysia, and anticipate future economic growth and industrialization. The call likely had an impact on people's perceptions of being pro-nuclear. Local leaders, especially governors, who are perceived by the community as open, trustworthy and honest, are likely to substantially influence the community regarding support for the use of nuclear energy ${ }^{(39,40)}$. In West Kalimantan, it seems that only very few groups are against this pro-nuclear stance.

On the other hand, after 2013, Bangka Belitung governors or community leaders never give clear statements on nuclear positions openly to avoid the controversy that might make them unpopular.

According to a previous national survey ${ }^{(16)}$, every statement on nuclear energy and other issues from a government figure is much more reliable than parliament or other public figures. Simultaneously, according to the OECD 2017 report, $80 \%$ of Indonesians trust the Government ${ }^{(41)}$. Indonesia's situation is unique; even when there is a crisis (including the Covid-19 pandemic), public trust in the Government remains high ${ }^{(42)}$. As a relatively young democracy (since the fall of the Suharto regime in 1998), it is possible that a remnant of the past culture still exists. During the past authoritarian Suharto regime, development was always controlled by the Government. The state regulates almost all aspects of public life. Society was put in a weak position. Through aid projects and other programs, the Government appears as a Santa Claus who gives everything to people.

\section{e. Uranium rich perception}

BATAN has been exploring the Kalan site in West Kalimantan since the 1960s, and the area has the potential for uranium of only 45,753 tons of uranium and 7,028 tons of thorium ${ }^{(43-45)}$. It is perceived by the local community that the NPP in West Kalimantan will be able to utilize that local uranium ${ }^{(38)}$. Even though BATAN explained that it is much cheaper to import uranium, it seems that the perception that they have enough uranium is difficult to lose.

In contrast, the Provincial Government of Bangka Belitung is very enthusiastic about using thorium as fuel for the "thorium power plant." Although it is not a common term internationally, the name of "thorium power plant" is promoted in Indonesia by the molten salt reactor vendors because they know some people are sensitive to the word "nuclear" ${ }^{(46,47)}$. Even though there is no thorium-based NPP commercially operational at this time, they believe that the use of thorium is safer and generates smaller waste than uranium-based reactors. The Provincial Government of Bangka Belitung refers to BATAN data that in their location, they have the potential for thorium around 126,821 tons, while uranium is 31,466 tons ${ }^{(45,48)}$.

This misunderstanding is probably because uranium and thorium researchers in Indonesia have difficulty explaining to the public and local governments that the data they provide is still in the status of indicated, not measured, or even proven.

The reasons a-d above are very situational and will change according to the improvement of electricity infrastructure in West Kalimantan. It will be interesting to conduct another study after the Government revises the electricity infrastructure 
and stops electricity imports from Malaysia to determine whether the level of support for nuclear remains as high as in 2019. However, in the future, energy demand in West Kalimantan is likely to increase rapidly in line with industrial development ${ }^{(38)}$, including the construction of the International hub of the Kijing port ${ }^{(49,50)}$, which is the largest on the island of Kalimantan. Many factors will influence the possibility of changing the West Kalimantan public's behavior and perceptions regarding nuclear energy use. Besides, as previously stated, in terms of nuclear impact, the West Kalimantan public has the same perception as the Bangka Belitung public; nuclear energy adverse effects are viewed as greater than the positives. It is possible that their reasons for supporting the development of nuclear power plants are quite fragile and may soon change with the development of electricity infrastructure in West Kalimantan.

As described above, although in general it can be said that West Kalimantan is more feasible for the construction of the first nuclear power plant in Indonesia than Bangka Belitung, it has potential problems that might disrupt the nuclear energy program. For decades, conflicts between ethnic groups in West Kalimantan, usually between indigenous people (Dayaks) and migrants (mainly Madurese), often caused many fatalities. Some researchers stated that cultural differences triggered the conflict, but some claimed it was a conflict of economic interests and identity politics. However, the situation is unique in that in neighboring provinces (South and East Kalimantan, which also have Madurese minorities), violence did not occur. A study shows that ethnic conflict may occur due to ethnic composition, cultural attitudes, competition for access to natural resources, and political competition. Furthermore, perhaps the most significant factor is that West Kalimantan is the poorest province among the Kalimantan provinces. Increasing the local community's welfare is one of the keys to national programs' success, including implementing the nuclear power plant program ${ }^{(27)}$.

The problem of sectarianism (involving ethnicity and religion) at the local and national levels was exacerbated after the democratization era began in 1998 following the fall of the Suharto regime. Demands for the rights of indigenous peoples, both politically and economically, are becoming increasingly prominent. The political representation can be resolved by relatively honest general elections that allow local politicians to emerge as proportional representations of all ethnic groups. However, there is still a perception of economic injustice, that the interests of migrants or the Central Government are more substantial, causing indigenous peoples to feel marginalized. In addition to conflicts between ethnic groups, a problem that often arises is the dispute over customary land ownership. Ancestral land (Tanah adat) is a legal term denoting communal rights of an (ethnic) community to land-based on that community's adat (custom or tradition). It is among the most intriguing concepts in Indonesian land law. These conflicts between indigenous ethnic groups and the Government have occurred in several strategic locations and often create obstacles to development in Kalimantan and other parts of Indonesia. These challenges may potentially be exploited by anti-nuclear groups who want to thwart the nuclear power plant development program.

Learning from the failure of the nuclear power plant development program in the past and paying attention to the conflicts that have occurred in West Kalimantan, the Government can take several actions:

1. Making the district where the prospective NPP location an exclusive economic zone with incentives in education, health, industry, and infrastructure.

2. Hold dialogues with informal ethnic leaders considered influential, including involving them in nuclear technology dissemination programs. The talk opened up opportunities to determine the local community's basic needs, thus minimizing the impression that the NPP program is top-down.

3. Invite the local stakeholders, such as academics, NGOs, and local entrepreneurs, to be actively involved in the nuclear energy program. The failure of the NPP program in Jepara, Central Java, in the past was probably because the central Government (in this case, BATAN) was considered too dominant without involving many local stakeholders.

\section{Conclusion}

The Government of Indonesia considers Bangka Belitung and West Kalimantan Provinces as potential locations for building the first nuclear power plants in the future. Both locations fulfill the NPP construction's seismological requirements to avoid earthquakes and tsunamis. Although this survey used a national nuclear power plant program theme, it was possible that respondents assumed that the nuclear power plant was associated with where they live, even without explicit mentions of the location. The public of West Kalimantan had a strong tendency to support the Indonesian nuclear power program. It might be because the fulfillment of electricity needs was still a constraint, and there were other supporting factors (especially the sentiment towards electricity imports from Malaysia). West Kalimantan is more likely to be the first location for nuclear power plants. In contrast, Bangka Belitung people who have negative memories of the past feasibility study and were satisfied with the current electricity supply with relatively more minor disruption tended to reject nuclear power plants.

The communities' geographical, demographic, and socio-cultural characteristics might influence respondents in considering nuclear energy use. The study results showed that the populace of Bangka Belitung tended to be more focused 
on local issues, while the West Kalimantan populace tended to be more insightful. The public of the two provinces had the same view of nuclear, which was that the negative impact was more significant than the positive. However, West Kalimantan's people's perception of nuclear power plants' construction was far more positive. It could be caused by electricity demand, sentiment towards Malaysia, and regional leaders who often express support for the development.

However, the perception of nuclear energy may change if the Government can meet West Kalimantan residents' electricity needs after several new power plants (coal-fired power plants) operate in the immediate future. If the Government decides to build a nuclear power plant in West Kalimantan by considering sustainability and long-term energy needs, then by learning from previous programs' failures, the Government must involve local stakeholders in every stage of the nuclear power plant program, including making the NPP candidate area an exclusive zone by paying attention to the local community's welfare.

\section{References}

1) Suharsono A, Lontoh L, Indonesia. Indonesia’s Energy Policy Briefing | July 2020. 2020.

2) The Indonesian Government, Government Regulation no. 79/2014 on National Energy Policy, Indonesia, 2014. Indonesia. $2014 . \quad$ Available from: https://jdih.esdm.go.id/index.php/web/result/186/detail.

3) Indonesia should focus on renewable energy, not nuclear, activists say - National - The Jakarta Post. 2021. Available from: https://www.thejakartapost. com/news/2020/03/12/indonesia-should-focus- on-renewable-energy-not-nuclear-activists-say.html.

4) Taking the nuclear option - Inside Indonesia. 2021. Available from: https://www.insideindonesia.org/taking-the-nuclear-option.

5) Time for nuclear power? Luhut tells tale of Indonesia 'having it all' - Business - The Jakarta Post. 2021. Available from: https://www.thejakartapost.com/ news/2020/02/04/time-for-nuclear-power-luhut-tells-tale-of-indonesia-having-it-all.html.

6) National Electricity Supply Business Plan (RUPTL) 2019-2028 (ESDM Decision No. 39 K/20/MEM/2019) | ESCAP Policy Documents Management. 2021. Available from: https://policy.asiapacificenergy.org/node/4172.

7) Budi BS. Study on effect of the NPP development toward spatial planning at District of Jepara. Gema Teknol. 2010;16:11-15. Available from: https://doi.org/10.14710/gt.v16i1.308.

8) and A. Recent Progress In The Study For First Power Plant In Indonesia. 1997. Available from: https://inis.iaea.org/collection/NCLCollectionStore/ _Public/28/031/28031542.pdf?r=1\&r=1.

9) Central Bureau of Statistics, Statistical Yearbook of Indonesia 2019, BPS, Jakarta, 2019. 2019.

10) Septiadi D, S YSB, Sriyana, Anzhar K, Suntoko H. An Extreme Meteorological Events Analysis For Nuclear Power Plant (NPP) Siting Project at Bangka Island, Indonesia. IOP Conference Series: Earth and Environmental Science. 2018;132(1):012009. Available from: https://dx.doi.org/10.1088/1755-1315/ $132 / 1 / 012009$.

11) Misnon FA, Hu YS, Rahman IA, Yasir MS. Malaysian public perception towards nuclear power energy-related issues. AIP Conf Proc American Institute of Physics Inc. 2017. Available from: https://doi.org/10.1063/1.4972904.

12) Ho JS, Looi ASF, Chuah AD, Leong N. Pang, "I can live with nuclear energy if...”: Exploring public perceptions of nuclear energy in Singapore. Energy Policy. 2018;120:436-447.

13) Ho SS, Oshita T, Looi J, Leong AD, Chuah ASF. Exploring public perceptions of benefits and risks, trust, and acceptance of nuclear energy in Thailand and Vietnam: A qualitative approach. Energy Policy. 2019;127:259-268. Available from: https://dx.doi.org/10.1016/j.enpol.2018.12.011.

14) Putra NA. The dynamics of nuclear energy among ASEAN member states. In: Energy Procedia;vol. 143. Elsevier BV. $2017 ;$ p. 585-590.

15) Nguyen VP, Yim MS. Examination of different socioeconomic factors that contribute to the public acceptance of nuclear energy. Nuclear Engineering and Technology. 2018;50(5):767-772. Available from: https://dx.doi.org/10.1016/j.net.2018.02.005.

16) Wisnubroto DS, Irawan DR, Erni T. Public opinion survey on nuclear energy in Indonesia: Understanding public perception on nuclear power plant program. AIP Conf Proc. 2019. Available from: https://doi.org/10.1063/1.5135551.

17) Ministry of Energy \& Mineral Resources of the Republic of Indonesia, Handbook of Energy and Economic Statistics of Indonesia 2018. Jakarta. 2018. Available from: https://www.esdm.go.id/assets/media/content/content-handbook-of-energy-and-economic-statistics-of-indonesia-2018-final-edition. pdf.

18) Achmad D. Potential and Challenges of Leading Sector Development in West Kalimantan. J Ekon Bisnis Dan Kewirausahaan. 2016;5:94-103. Available from: https://doi.org/10.26418/jebik.v5i2.17142.

19) Susiati H, Sbs Y, Anzhar K, Kironi B, Mellawati J. Application of remote sensing data and GIS in selecting potential measures of NPP in West Kalimantan. J Pengemb Energi Nukl. 2015;17. Available from: https://doi.org/10.17146/jpen.2015.17.2.2608.

20) Bappenas R, Pembangunan. Rencana Pembangunan Jangka Menengah Nasional 2020 - 2024. 2019. Available from: https://www.bappenas.go.id/files/ rpjmn/Narasi-RPJMN-2020-2024-versi-Bahasa-Inggris.pdf.

21) Salsabila K, Saraswati R, Shidiq PA, Susiati H. To cite this article: K Salsabila et al. 2021 IOP. Conf Ser Earth Environ Sci;623. Available from: https://doi.org/10.1088/1755-1315/623/1/012049.

22) Central Bureau of Statistic, Statistical Yearbook of Indonesia 2017, Jakarta, 2018. Jakarta. . Available from: https://www.bps.go.id/website/pdf_publikasi/ Statistik-Indonesia-2017.pdf.

23) Central Bureau of Statistics, Statistical Yearbook of Indonesia 2018, Jakarta, 2019. . Jakarta. .

24) Widjonarko S. Grassroots community response to the discourse of country production defense (a case study of grassroots communities in. In: University of Gadjah Mada Yogyakarta. 2012.

25) Wijayanti TE. Public Concern Dalam Isu Energi Nuklir : Studi pada Level Nasional dan Lokus Calon Tapak PLTN Propinsi Bangka Belitung, (2017). . Available from: http://repo-nkm.batan.go.id/653/.

26) NDONESIA INTERNET SERVICE PROVIDER ASSOCIATION, Penetration and behavior of Indonesian internet users 2017, Jakarta, 2017. . Available from: https://www.apjii.or.id/content/read/39/342/Hasil.

27) Jurnal L, Herawati N, Sudagung A. Jurnal Pengembangan Energi Nuklir Persepsi Masyarakat dan Potensi Public Acceptance Terkait Wacana Pembangunan PLTN di Kabupaten Bengkayang. 2020. Available from: https://doi.org/10.17146/JPEN.2020.22.2.6125. 
28) Setiawan D. Potential Sites Screening for Mini Hydro Power Plant Development in Kapuas Hulu, West Kalimantan: A GIS Approach. Energy Procedia. 2015;65:76-82. Available from: https://doi.org/10.1016/j.egypro.2015.01.034.

29) Gokhale EP, Date A, Akbarzadeh A, Bismantolo P, Suryono AF, Mainil AK, et al. A Review on Micro Hydropower in Indonesia. Energy Procedia. 2017;110:316-321. Available from: https://dx.doi.org/10.1016/j.egypro.2017.03.146.

30) Yudha SW, Tjahjono B, Longhurst P. Stakeholders' Recount on the Dynamics of Indonesia’s Renewable Energy Sector. Energies. 2021;14(10):2762-2762. Available from: https://dx.doi.org/10.3390/en14102762.

31) Indonesian State Electricity Enterprise, PLN Statistics 2018, Jakarta, 2019...

32) . 2017.

33) Government W, Kalimantan. Pontianak. 2019. Available from: https://esdm.kalbarprov.go.id/wp-content/uploads/2020/07/Draft-Narasi-RUED-PKalbar.pdf.

34) Herti RS. The Impact of Electrical Power Interconnection Cooperation Between West Kalimantan and Sarawak in Increasing Economic Growth Potential in West Kalimantan. Journal of Islamic World and Politics. 2020;4(2). Available from: https://dx.doi.org/10.18196/jiwp.4255.

35) Holst F. (Dis-)Connected History: The Indonesia-Malaysia Relationship, Indones. Presence Past. A Festschrift Honour Ingrid Wessel. $2007 ;$ p. 327-340. Available from: http://www.regiospectra.com.

36) Khalid KM, Yacob S. Managing Malaysia-Indonesia relations in the context of democratization: the emergence of non-state actors. International Relations of the Asia-Pacific. 2012;12(3):355-387. Available from: https://dx.doi.org/10.1093/irap/lcr024.

37) West Kalimantan wants its Nuclear Power Plant. 2020. Available from: https://nbn.media/west-kalimantan-wants-its-nuclear-power-plant/.

38) The Impacts of Nuclear Power Plant Construction in West Kalimantan - The Purnomo Yusgiantoro Center. 2021. Available from: https://www. purnomoyusgiantorocenter.org/the-impacts-of-nuclear-power-plant-construction-in-west-kalimantan/.

39) Sugiawan Y, Managi S. Public acceptance of nuclear power plants in Indonesia: Portraying the role of a multilevel governance system. Energy Strategy Reviews. 2019;26:100427. Available from: https://dx.doi.org/10.1016/j.esr.2019.100427.

40) Stiglitz J. Transparency in Government. In: Role Mass Media Econ. Dev. 2002;p. 27-44. Available from: https://documents1.worldbank.org/curated/en/ 957661468780322581/pdf/multi0page.pdf.

41) Government at a Glance 2017. OECD. 2017. Available from: https://doi.org/10.1787/gov_glance-2017-en.

42) Sentimen Publik Nasional terhadap Kondisi Ekonomi dan Politik 2020 dan Prospek 2021 - SaifulMujani. 2021. Available from: https://saifulmujani.com/ sentimen-publik-nasional-terhadap-kondisi-ekonomi-dan-politik-2020-dan-prospek-2021/.

43) Ciputra R, Suharji S, Kamajati D, Syaeful H. Application of geostatistics to complete uranium resources estimation of Rabau Hulu Sector, Kalan, West Kalimantan. E3S Web of Conferences. 2020;200:06001. Available from: https://dx.doi.org/10.1051/e3sconf/202020006001.

44) Application of UNFC for reassessment of uranium resources of the Eko Remaja and Rabau Sectors, Kalan Area, West Kalimantan, Indonesia. 2021. Available from: https://www.un-ilibrary.org/content/books/9789210045254c015.

45) Nea, Uranium Resources, Production and Demand A Joint Report by the Nuclear Energy Agency and the International Atomic Energy Agency NEA NUCLEAR ENERGY AGENCY, 2020. 2020. Available from: https://www.oecd-nea.org/jcms/pl_52718/uranium-2020-resources-production-anddemand?details=true.

46) ThorCon Progress in 2020.

47) Rencana Pembangunan Pembangkit Listrik Tenaga Nuklir Berbahan Bakar Torium oleh Swasta - Ilmu dan Teknologi. 2021.

48) International Atomic Energy Agency (IAEA), WORLD THORIUM OCCURRENCES, DEPOSITS AND RESOURCES, Vienna, 2019. 2019.

49) Nur TH, Achmadi K, Mercy. Earth and Environmental Science Analysis of Seven International Indonesian Hub Ports Policy Development Impact on Shipping and Port Sector Analysis of Seven International Indonesian Hub Ports Policy Development Impact on Shipping and Port Sector. IOP Conference Series. Available from: https://doi.org/10.1088/1755-1315/557/1/012061.

50) Indonesia plans new deep-sea port | JOC.com. 2021. Available from: https://www.joc.com/port-news/asian-ports/indonesia-plans-new-deep-sea-port_ 20151114.html. 